\title{
Groundwater Pumping Irrigation in Haryana: Issues and Challenges
}

\author{
Ashok Kr Duhan \\ Lecturer in Geography Haryana Education Department
}

\begin{abstract}
This paper finds out the impacts of groundwater pumping irrigation on level of ground water. It has been observed that continuous pumping caused decreasing of groundwater level after Green Revolution. Groundwater has speedily emerged to occupy a paramount role in India's agriculture after green revolution. In Haryana groundwater pumping has become the main means of irrigation and it now accounts for over about 54 percent of the irrigated area in state. Intensive agriculture dominated by paddy-wheat mono-culture has led to overexploitation of groundwater in Haryana. It is leading for a crisis and needs most urgent attention and understanding in India mainly in original Green Revolution states comprising, Punjab, Rajasthan and Haryana vulnerable to severe water scarcity. As per the latest assessment by the Central Ground Water Board (CGWB), Delhi, Punjab, Rajasthan and Haryana consume much more groundwater than their rechargeable limit every year, making them vulnerable to severe water shortage. In Punjab and Haryana, the offender is the indiscriminate use of groundwater in agriculture (India water portal organization).The paper is based on both primary and secondary data.
\end{abstract}

Keywords: pumping irrigation, green revolution, vulnerable, monoculture.

\section{INTRODUCTION}

Groundwater irrigation has played an important role in success of Green Revolution in India particularly in original Green Revolution states comprising Haryana, Punjab and western Uttar Pradesh. Haryana is an agriculturally developed state. About 80 percent of the total geographical area of the state is under cultivation. Out of which about 84 percent cultivable land have irrigation facilities. Therefore water demand from agriculture in the state is very high.

It is well noticed that much of the increase in green revolution wheat and rice crops as well as commercial crop area of the state has come from areas in which traditional rain-fed crops were grown. Farmers began to adopt more water intensive crops which required protective irrigation that was fulfilled by ground water pumping. About $89 \%$ of groundwater extracted is used in the irrigation sector, $9 \%$ is for domestic use and 2\% is for industrial use (India water Portal).Irrigation plays a major role in green revolution technologies and within this, groundwater irrigation is the best (Moench2003). Ot -her research indicates that yields in groundwater irrigated areas are higher by onethird to one-half as compared to those from areas irrigated by surface sources (Dhawan 1995).

In Haryana requirement protective irrigation increased yearly and dependency on groundwater pumping irrigation also increased. But continue extraction of groundwater through tube well, the lap of earth has been drying. State has 8lac 44thousand tube well which are extracting water from the lap of earth. Ground water decline rate in case of Haryana had been estimated about $35 \mathrm{~cm}$ per annum (Chatterjee and Purohit, 2009). From 1999 to 2017 the depth of the underground water in state has reached double time (Amar Ujala, 16April, 2017).

A study by National Academy of Agricultural Sciences in 2011 reads, "Water-table in 82 per cent area of Punjab and 63 per cent of that in Haryana has gone down substantially," the study said and further mentioned, "In Haryana, only 37 per cent of the water is exploited within the safe limits while 14 per cent over-exploitation has reached a semi-critical to a critical stage."

\section{OBJECTIVE}

1. This paper find outs the main cause of groundwater depletion.

2. To suggest some preventive and curative measures for sustainable uses of underground water 


\subsection{Study Area}

Haryana state, located between $27^{\circ} 30^{\prime}$ and $30^{\circ} 35^{\prime} \mathrm{N}$ latitude and $74^{\circ} 28^{\prime}$ and $77^{\circ} 36^{\prime} \mathrm{E}$ longitude. It is a part of the north western arid and semiarid plains with an average rainfall of $545 \mathrm{~mm}$. The state has the Shivalik hills in the north, the Aravalli range in south western, river Yamuna in the east and the river Ghaggar provides a kind of boundary in the west of the state. State has four differences regions that are northern, eastern, western and southern regions. All the four are regions distinct from one another in relief, climate, soils, and water characteristics. The northern part is hilly; the eastern part is getting higher rainfall, fertile soil and slopes north to south with a height between 700 and 900 feet. The south-western part is dry, sandy and barren. Haryana is an agriculturally developed state and its agriculture based on fertile land and irrigation facilities .Although there is no perennial river, but canal irrigation is developed, based on western Yamuna canal system and bhakhra canal system. After Green revolution tube well irrigation emerged an important source of irrigation. There are 8 lac44thousand Tube Well in state that are drawing water from the lap of earth (Amar Ujala, 16April, 2017). Although tube well irrigation is urgent need of agriculture in the state but due to adopt of monoculture of rice and wheat and mainly rice crop the groundwater is over exploited. And there is problem occurred underground water depletion. So we should consider that problem immediately.

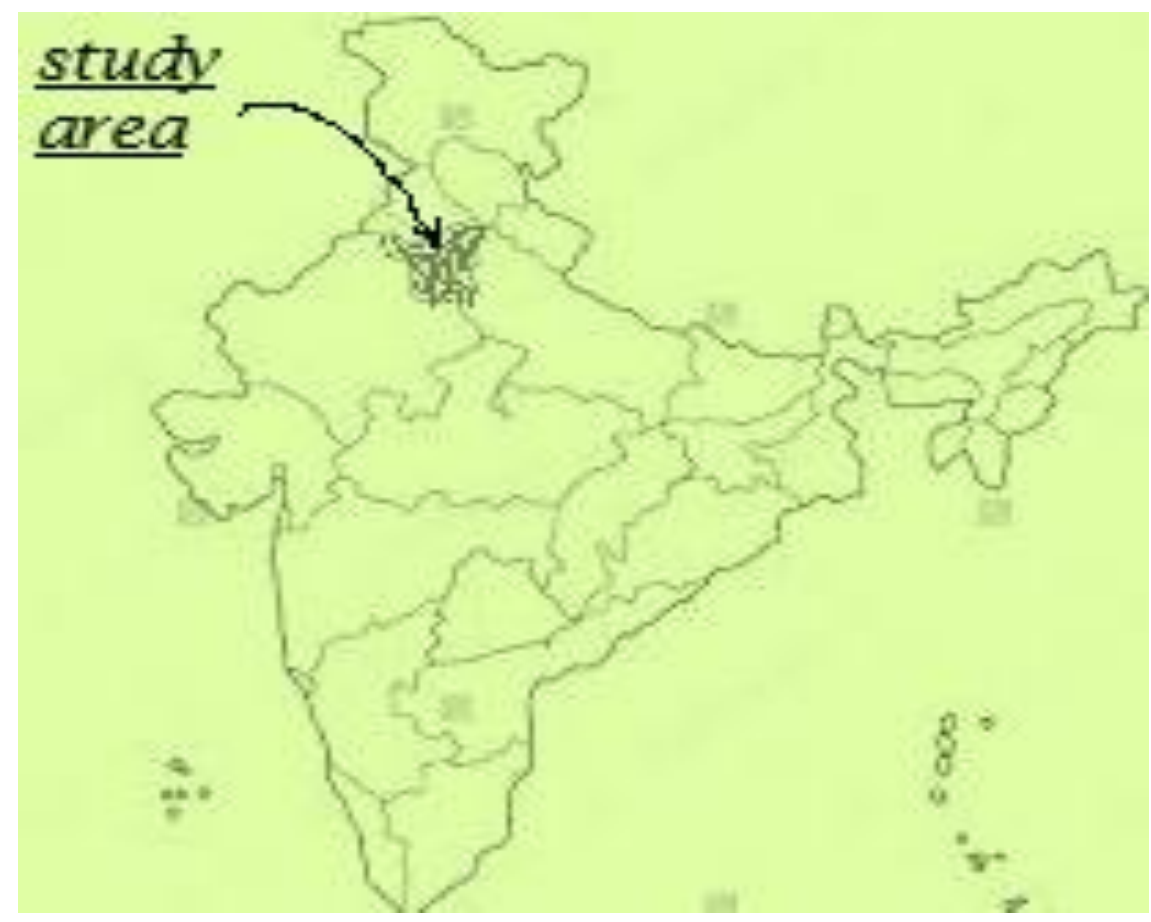

\section{DAta Source AND Methodology}

In this research paper the researcher used both primary and secondary sources of data. Primary data has been collected through the field survey and secondary data from different department and statistical abstract of Haryana and newspapers. Increasing of number of tube wells\& pump sets from 1970to 2014-15 and decreasing of groundwater level in different districts from june1999to june2016 are showing drastic effect on groundwater level that are cleared by table A and B:

TableA. Number of Tube-Wells \&Pump Sets in Haryana (1970-71 To2014-15)

\begin{tabular}{|c|c|c|}
\hline S.No. & Year & $\begin{array}{c}\text { Number of tube wells \&pump sets } \\
\left(\mathbf{x 1 0}^{\mathbf{3}}\right)\end{array}$ \\
\hline 1. & $1970-71$ & 104 \\
\hline 2. & $1980-81$ & 332 \\
\hline 3. & $1990-91$ & 498 \\
\hline 4. & $2000-01$ & 589 \\
\hline 5. & $2009-10$ & 677 \\
\hline 6. & $2013-14$ & 772 \\
\hline 6. & $2015-16$ & 843 \\
\hline
\end{tabular}

Data source statistical abstract of Haryana, Govt. of Haryana 
Groundwater Pumping Irrigation in Haryana: Issues and Challenges

TableB. Groundwater Level in Meters in Different Districts in Haryana from (June 1999- June 2016)

\begin{tabular}{|c|c|c|c|}
\hline Districts & June,1999 & June,2016 & Depth \\
\hline Ambala & 5.45 & 11.24 & 5.79 \\
\hline Bhiwani & 16.19 & 21.97 & 8.78 \\
\hline faridabad & 8.71 & 17.65 & 19.56 \\
\hline Fatehabad & 6.42 & 25.98 & 13.65 \\
\hline Gurugram & 15.22 & 28.87 & 1.95 \\
\hline Hisar & 5.92 & 7.82 & 8.56 \\
\hline Jind & 5.87 & 14.48 & 0.61 \\
\hline Jhajjar & 4.49 & 5.10 & 18.05 \\
\hline Kurukshetra & 17.25 & 35.30 & 18.91 \\
\hline Kaithal & 7.78 & 26.69 & 11.16 \\
\hline Karnal & 7.59 & 18.75 & 21.38 \\
\hline Mahendragarh & 25.01 & 46.39 & 4.39 \\
\hline Mewat & 7.14 & 11.53 & 4.83 \\
\hline Palwal & 5.72 & 10.55 & 10.28 \\
\hline Panipat & 8.53 & 18.81 & 0.30 \\
\hline Rohtak & 3.80 & 4.10 & 13.90 \\
\hline Rewari & 13.07 & 26.97 & 3.75 \\
\hline Sonipat & 5.33 & 9.08 & 11.03 \\
\hline Sirsa & 9.45 & 20.48 & 5.83 \\
\hline Yamunagar & 7.13 & 12.96 & 5.9 \\
\hline Panchkula & 11.17 & 17.15 & 9.30 \\
\hline Total Average & 9.36 & 18.66 & \\
\hline
\end{tabular}

Source: Amar Ujala, 17 April 2017

\section{Result}

Above table shows that the ground water level in the state has been depleted about double depth in last 17 years.

Some northern districts has more affected than other parts of state, its main cause of high exploitation of groundwater through tube-well because in northern districts like Kaithal, Karnal, Panipat, Kurukshetra, Fatehabad and Sirsa are the under cultivation of mono culture of rice and wheat and Increased Cropping intensity accompanying access to groundwater resource has favored maximum exploitation of water resource by growing high water requiring crops like rice, wheat, sugarcane and cotton in favor of traditional low water requiring crops. Kaithal and Fatehabad are worst affected of ground water depletion, because these districts ground water level has been depleted about 4x. But in middle districts like Rohtak \& Jhajjar are least affected because their topography is like bowl shape.

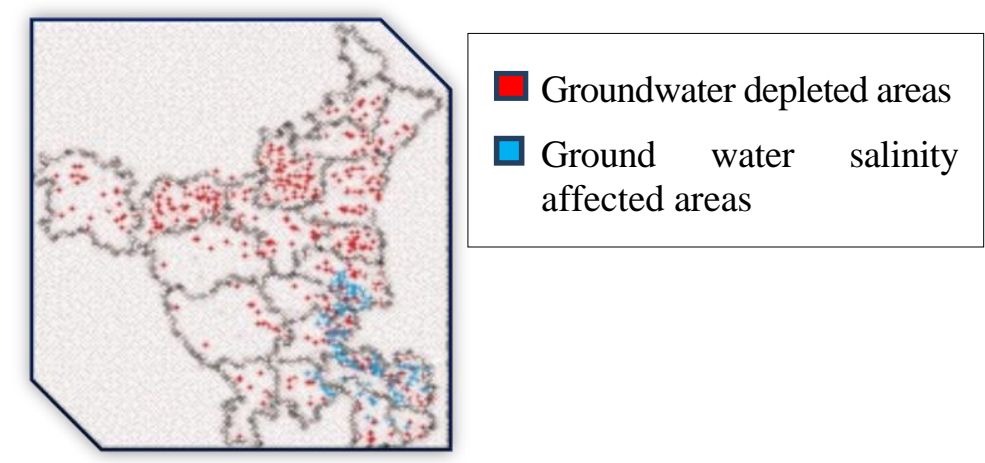

In many district farmers told their problems to researcher that every year groundwater level in their fields is going down as a result farmer have to invest in submersible more and more. Farmers have to face financial problems. In many areas of the state the ground water has become salty particularly some parts of NCR districts. Those areas are shown in above map bylight blue colour.

\section{SUGGESTION}

We should adopt efficient irrigation practices like drip and sprinkle irrigation; free eccentricity should be stopped because it is main causes to indiscriminate use of groundwater in agriculture. Rainwater is 
a prominent source of water that can be alternatively conserved for using in agriculture and recharge of groundwater reservoir. Crop diversification is an important substitute to sustain agriculture and farmer. We must adopt scientific methods of agriculture like sowing less water consuming crops, dry farming.

Finally reduction of groundwater pumping can be achieved through strict state government groundwater regulation.

\section{REFERENCES}

[1] Data source statistical abstract of Haryana, Govt. of Haryana (1969-70 to 2014-15)

[2] Moench, Marcus (2003), 'Groundwater and Food Security in India', in Kamta Prasad (ed.), Water Resources and Sustainable Development Shipra Publication,Delhi,pp148-67.

[3] Dhawan, B.D. (1982),(1995), Groundwater Depletion, Land Degradation, and Irrigated Agriculture in India, Commonwealth Publishers, New Delhi.

[4] A study by National Academy of Agricultural Sciences in 2011.

[5] Amar ujala, 17 April 2017.

[6] Chattergee R and Purohit R R (2009) Estimation of repenishable groundwater resource of India and their status of utilization, current science 96:1581-1591.

[7] National academy of agriculture science (2001)

[8] India water portal organization by Swati Bansal

\section{AUTHOR'S BIOGRAPHY}

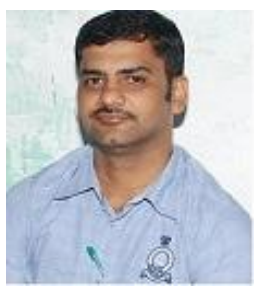

Ashok kr Duhan, got the degree MAin Geography from MDU Rohtak in 2002-03. $\mathrm{He}$ is a lecturer in geography in Haryana education department. He has nine year teaching experience. He cleared Six times UGC/NET and three times JRF and also URS. He has published five research papers in International Journals and he has also presented three research papers in different National and International seminar. He has attended two refresher courses in NCERT and SCERT. He has also attended certificate course of remote sensing and GIS in HARSAC. 